Article

\title{
Exploratory Analysis of the Relationship between Happiness and Religious Participation within China
}

\author{
Tianyuan Liu ${ }^{1}$, Lin $\mathrm{Wu}^{1, *}$, Yang Yang ${ }^{1, *}$ and $\mathrm{Yu} \mathrm{Jia}^{2}{ }^{2}$ \\ 1 School of Sociology, Wuhan University, Wuhan 430072, China; ltyuan@whu.edu.cn \\ 2 School of Journalism and Communication, Wuhan University, Wuhan 430072, China; jiayu219@whu.edu.cn \\ * Correspondence: wlin@whu.edu.cn (L.W.); yangyangwhu@whu.edu.cn (Y.Y.)
}

Received: 11 May 2020; Accepted: 27 July 2020; Published: 8 August 2020

\begin{abstract}
Although the positive relationship between religion and happiness has aroused heated debate, empirical studies on this are limited in the Chinese cultural context. Furthermore, there is a lack of heterogeneity analysis concerning this influence. This paper aims to address this gap in the existing literature. Using the Chinese General Social Survey data from 2015 for empirical analysis, the results show that people with religious beliefs have an increased probability of feeling very happy. This positive association does not exist in urban and eastern groups, but it still holds up in other remaining sub-samples (i.e., rural group). This study further finds that the effect of religiosity on happiness varies by different religious identification. Muslims are more likely to feel very happy compared with non-Muslims, but people of the Christian faith do not rate themselves higher on the happiness scale than non-Christians. Moreover, the results also reveal that religious involvement is significantly and positively related to happiness. Specifically, vulnerable groups are more likely to perceive themselves to be happier from continuous religious participation, whereas advantaged groups do not. This is because vulnerable groups generally have a lack of social security, and religious practices provide them with social support among their members. They therefore can enjoy larger and denser social networks. These are vital mechanisms for them to cope with stress and risk.
\end{abstract}

Keywords: happiness; religion affiliation; religious involvement; social support; China

\section{Introduction}

In recent years, the amount of research on the factors affecting happiness has increased. Abundant studies have found that individual income is a key factor. The growth of individual income brings about a rich material life and promotes continuous improvement of clothing, food, housing, and transportation, such as spacious houses, luxury cars, etc. This enhances people's individual life satisfaction and happiness (Diener 1984; Diener et al. 1985). However, studying the relationship between U.S. residents' income and happiness after World War II, Easterlin (1974) found that the happiness of residents did not improve according to the logic of previous research. This discovery aroused widespread debate among scholars in the fields of economics, psychology, and sociology, and was later named the "happiness paradox." It argues that the satisfaction and improvement of material life do not necessarily yield happiness. This is because spiritual pleasure is also vital for people to find happiness. Religious belief is one of the important manifestations of the spiritual level. We therefore cannot ignore the influence of religious beliefs on an individual's happiness. Theoretically, religious beliefs may provide some guiding tools for people to change their spiritual world, including their doctrinal spirit and value proposition (Azzi and Ehrenberg 1975), thus enabling believers to recover from the hardships and frustrations of unemployment, divorce, and bereavement more quickly and thoroughly (Ellison 1991). A large amount of evidence shows that happiness is related to religious beliefs or religious behavior (Abu-Raiya et al. 2016; Campante and Yanagizawa-Drott 2015; Myers 2000; 
Ferriss 2002; Snoep 2008). For example, Levin (2014) adopted different dimensions to measure religion, and every religious measure is positively and significantly associated with happiness.

Why are religious people happier than nonreligious people? Some literature identified several mechanisms by which religion affects happiness, including social networks (Chen and Williams 2016; Lim and Putnam 2010), the social norm of religiosity (Stavrova et al. 2013), positive emotions (Wilkins 2008; Fredrickson 2002), and the meaning of religion (Krok 2014; Park 2005). For example, Fredrickson (2002) adopted the broaden-and-build theory to analyze how religion benefits well-being, finding that religious believers enjoy more positive emotions compared with nonbelievers. These positive emotions can, in turn, help them to broaden their mindsets and have a great attitude towards daily life or life challenges (e.g., a diagnosis of cancer), and finally enhance their well-being. Previous studies can help us to further perceive the relationship between religion and happiness.

However, these studies are generally based on Western cultural contexts, with whites or Christians occupying a dominant position among the respondents (Levin 2014). Few studies have examined whether the relationship between religion and happiness exists in the context of Chinese culture (Sun and Zhang 2019). Brown and Tierney (2009) used data from the Chinese Longitudinal Healthy Longevity Survey to study the oldest people (older than 80). After controlling for factors such as population, health and disability, living arrangements, wealth and income, lifestyle, social networks, and geographic location, the results showed a strong negative correlation between religious participation and well-being. Lu and Gao (2017) divided religious faith into three dimensions: religious identity, religious beliefs, and religious practices, and explored their relationship with happiness separately. The study reported that, in general, religious identity is not associated with happiness, but religious beliefs and religious practices are negatively related to happiness. Remarkably, Zhang et al. (2019) used data from the 2007 Spiritual Life Study of Chinese Residents and found that religion positively correlates with happiness among those with religious affiliations in China. There is a major controversy about the relationship between religion and happiness in the cultural context of China in the existing literature. This relationship is positive or negative and requires further discussion and repeated tests with more sample data.

In addition, when talking about Chinese religious issues, some scholars may suggest that religion cannot play an active role in China. The conclusion may be based on the following three aspects. Firstly, China's ruling party, the Communist Party, regards Marxist atheism as its official ideology. By the end of 2018, the total number of members of the Communist Party of China had reached about 90.6 million, and the members all tended to be an atheist. Secondly, a significant percentage of Chinese citizens explicitly claimed that they are religious nonbelievers (Yang and Hu 2012), and this was different from the U.S. where people are generally religious. Indeed, some literature indicated that atheists are less accepted than other marginalized groups in the U.S. (Edgell et al. 2006). Thirdly, since the era of Mao Zedong, the Chinese government has implemented specialized supervision and management of various religious affairs (Yang 2006). This is different from some countries that have not been subject to religious market control. In fact, religion plays an important role in the development of Chinese society. With the intensification of social competition and the imbalance of social development in recent years, public status anxiety is becoming more prominent (Chen and Williams 2016; Chen and Fan 2015), and many people are turning to traditional religions to seek comfort and transfer discontent. Therefore, the number of religious believers and religious activities has experienced a significant growth (Lu 2012). Ashiwa and Wank (2006) and Yang (2010) noted this phenomenon and urged religious-based research in China.

In summary, we aim to fill the gap in the existing studies in this paper and respond to the call of Ashiwa and Wank (2006) and Yang (2010) by presenting a case study of mainland China. First, based on social support theory, we shine light on analyzing the impact of religious beliefs of the Chinese people on their happiness. Meanwhile, we further compare how different religious beliefs (i.e., Buddhism, Christianity, Islamism) may exert various influences on happiness. Second, we examine whether this 
influence is heterogeneous due to differences in gender, household registration, years of education, and area of residence.

\section{Religion and Religious Participation in Contemporary China}

Since the founding of the People's Republic of China in 1949, the Communist Party of China has adopted a Marxism-Leninism attitude toward religion, attempting to supervise and regulate various religious affairs. Therefore, religious activities have been greatly reduced from 1949 to 1976. After the reform and opening-up in 1978, China became more open to civil differences and disputes and reduced the mandatory collective orthodoxy. The religious policy direction of the party and the state has also shifted from radical atheism (with the purpose of completely eradicating religion to pragmatism) to a limited tolerance for religion (MacInnis 1996; Nanbu 2008). In 1982, the government issued "Document 19," which recognized religion as a historical phenomenon in the development of human society to a certain stage, and understood that it has its process of occurrence, development, and extinction. Religious beliefs, religious feelings, religious ceremonies, and religious organizations that are compatible with such beliefs and feelings are the products of the history of society. Concurrently, the government would respect and protect the belief of people in five legal religions: Buddhism, Daoism, Islam, Catholicism, and Protestantism (Potter 2003). In 2005, the People's Republic of China State Bureau of Religious Affairs publicly admitted that family members and friends can gather at home for worship without having to register with the government. Since then, religion has awakened in China and has experienced a period of rapid growth in the number of religious believers (Stark and Liu 2011).

According to the white paper entitled "China's Policies and Practices to Guarantee Freedom of Religious Belief" released by the Chinese government in April 2018, China currently has more than 144,000 places for religious activities that are registered according to law, about 33,500 Buddhist temples, more than 9000 Daoist temples, and over 35,000 Islamic mosques. There are 98 Catholic dioceses, more than 6000 churches, and about 60,000 Christian churches and meeting places. There are about 5500 various religious groups, more than 380,000 religious staff, 91 religious colleges, and nearly 200 million religious citizens.

Some survey data confirmed that the proportion of religious beliefs is rising rapidly, while the proportion of atheists is declining ( Xu et al. 2017). For example, in the second round of The World Values Survey in 1990, the proportion of atheists was nine times that of believers, but in the fourth round of the survey published in 2001, it fell to half that, and $13.1 \%$ of Chinese were religious in the sixth round conducted in 2012. Besides, the make-up of the believer has changed dramatically. According to data from the Chinese General Social Survey in 2006 (National Survey Research Center 2006) and 2013 (National Survey Research Center 2013), we found that about 52.5\% of adherents were rural residents in 2006, whereas the percentage reached approximately $56.7 \%$ in 2013 . In the two waves of the survey, religious believers consisted largely of women, and the proportion of male believers experienced a growth from $37.4 \%$ to $40.6 \%$. Moreover, most of these adherents achieved a lower educational attainment, and the proportion showed a growth ranging from $71.7 \%$ to $73.3 \%$. By contrast, the percentage of highly educated believers was reduced from $28.3 \%$ in 2006 to $26.7 \%$ in 2013. With respect to the geographic regions, the CGSS 2006 showed that about $54.5 \%$ of religious people lived in the eastern regions, whereas the proportion decreased to nearly $45.5 \%$ in the CGSS 2013 (National Survey Research Center 2006, 2013). The scale of believers living in the middle regions increased by about 10\% from 2006 to 2013, and the proportion of adherents in the western areas stayed constant from 2006 to 2013.

In addition, some scholars even assert that "a wave of religious climate is sprouting in China" (Yang 2010). Religion has become an indispensable part and another significant feature in China. We therefore argue that it is necessary to explore the relationship between religion and happiness in the context of Chinese culture. 


\section{Conceptual Framework}

A large body of research has suggested that religiosity or religious involvement generally plays a positive role in promoting happiness (Mochon et al. 2011; Snoep 2008). Social support theory provides a good way to analyze the relationship between religion and happiness (Krause et al. 2001; Ellison and Levin 1998). This theory posits that an individual has access to gain support (e.g., emotional, tangible, and informational assistance) through social ties to other individuals, groups, and the larger community (Lin et al. 1979). As implied by this theory, one critical reason for the relevance of religion to happiness is that the adherents who share the same religion and practices have more in common, and can arrive at a high level of social integration. This can serve to create social ties (Sosis 2000) and achieve social support from religious members and groups (Chatters 2000; McFarland 2010). It benefits and improves their happiness. In other words, the religious settings build a platform from which coreligionists can ask for and exchange emotional or tangible support. Since adherents build strong social ties during the interaction, religious involvement that provides social support to members and encourages them to remain hopeful in the face of difficulties is especially beneficial to enhance happiness (Ellison et al. 1989; Lim and Putnam 2010). Accordingly, we argue that religiosity is likely to play a salutary role for the groups that do not have widespread social support. This is because religious faith and attendance provide a social security network for them. On the contrary, the positive effect of religiosity may be limited for some people with more social capital. Generally, a high education level reflects high socioeconomic status and social support (Ajrouch et al. 2005). Thus, we infer that the effect of religiosity on happiness can vary by educational attainment.

Gender socialization demonstrates that men tend to be aggressive and independent through socialization, but women are socialized to be obedient and nurturing (McFarland 2010). Beit-Hallahmi and Argyle (1997) argued that women are more religious than men, and they are keen to participate in the religious practices. This is because some female traits are consistent with the religious value proposition, for example, compliance with religious doctrine and canon. Women may improve their happiness through religious faith and activities, whereas the salutary effects are less significant for males because they do not play a central role in male life (Moberg 1965). Even so, some studies report that women are more likely to occupy a subordinate status in religious settings (Heyer-Gray 2000). They are usually responsible for cleaning-up, cooking, and other supporting work, whereas men are more likely to lead or say prayers in religious activities. Accordingly, Brown and Tierney (2009) pointed out that religion has a larger effect on male happiness than female. In summary, we found that the effect of religion on happiness varies by gender, which is a longstanding controversy in previous studies. Thus, considering the uniqueness of religious development in China, will the gender differences result in variance on the influence that religion exerts on happiness?

In addition, the positive effect of religion on happiness also depends on certain cultural and economic contexts (Lun and Bond 2013). Eichhorn (2011) documented that the differences in societal-level religiosity tend to impact greatly on a person's attitude toward religion and his or her happiness. In other words, the association between religion and happiness is likely to be stronger in the society or region with a higher level of religiousness. Apart from the cultural contexts, the economic contexts are also vital to understand the relationship between religion and happiness. One important theoretical approach to the connection between religion and the political posits that some economic events (e.g., economic growth) exert influence on religious attendance or beliefs (Barro and Mitchell 2004). For example, Diener et al. (2011) surmised that religion is necessary for those people living in difficult circumstances. In general, economically developed nations have a higher level of social security and a better infrastructure that can meet their needs (Snoep 2008). They can easily achieve a high level of happiness without the help of religious faith and members. Thus, these studies showed that the influence of religion on happiness is different as a function of cultural and economic contexts (Lun and Bond 2013). It is generally known that the "hukou," China's household registration system, is a special cultural context, and Chinese residents are divided into urban and rural residents. On average, rural residents have a higher level of religiousness, and urban residents 
a lower level. Moreover, after 40 years of reform and opening-up, China's regional and economic development has shown imbalances. Specifically, the eastern regions have arrived a high level of economic and social development, but there are relatively more ethnic minorities and poor people in the western regions, and the overall development of the central regions falls somewhere in-between. The geographic locations (eastern, middle, and western regions) are the most representative economic contexts. Based on these leads, we infer that the relationship between religion and happiness varies in urban and rural residents, and in the eastern, middle, and western regions.

\section{Data and Methods}

\subsection{Data}

The data used in this paper are from the Chinese General Social Survey (CGSS), as the counterpart to the U.S. General Social Survey. The CGSS was jointly initiated by several famous Chinese universities in 2003. It is the earliest, most nationwide, comprehensive, and continuous academic survey project in China. So far, the CGSS data set has been developed for more than ten years, forming a multi-period cross-section data repository, which has become one of the most important national representative data sources about Chinese research (for more information, see http://www.cnsda.org). To get relatively accurate information, the CGSS adopts a door-to-door approach to interviewing. Investigators acquire proper training in advance, ensuring that they are qualified for this work. When conducting a household survey in the rural regions, the investigators are required to help the respondents clearly understand the meaning of each item, ensuring the accuracy of the respondents' answers. To reflect the situation closest to the present, we adopted the latest published CGSS 2015 data from 2018. The CGSS 2015 employed a four-stage, stratified, cluster sampling method, and its sample covered 478 neighborhoods in 28 mainland provinces, municipalities, or autonomous regions in China (National Survey Research Center 2015). The respondents were mainly adults aged 16 and older. Based on the individual and family level, the CGSS 2015 comprehensively measured the survival and development status of urban and rural residents, including marriage, education, interpersonal relationships, career development, income level, physical and mental health, and happiness. In summary, data from CGSS 2015 include not only the descriptions of respondents' objective features, but also the feedback on their subjective perceptions. The sample size was large, and the distribution area was relatively wide, so this data set provided important evidence for exploring the relationship between religion and happiness in the Chinese context. The CGSS 2015 received a total of 10,968 samples. Our working sample consisted of 7882 Chinese residents from 461 neighborhoods, after removing the missing values of the dependent, independent, and other important variables.

\subsection{Measures and Methods}

\subsubsection{Measures of Happiness}

Happiness, a feeling that everyone desires, is a psychological outcome (Rizvi and Hossain 2017), including the individual's cognitive judgments of satisfaction and the affective appraisals of emotions. Based on previous research, we learned that most researchers used a single self-report item to measure it (Abu-Raiya et al. 2016; Levin 2014). For example, Andrews and Withey (1976) asked respondents "How do you feel about your life as a whole?" with seven possible answers that ranged from delighted to terrible. Abdel-Khalek (2006) also pointed out that it is feasible and effective to measure happiness with a single-item scale in community surveys and cross-cultural comparisons. We therefore employed a single item to measure happiness. Respondents were asked to answer the question "In general, how happy do you feel about your life?" They were provided with a five-point scale consisting of the following responses: very unhappy, unhappy, so-so, happy, very happy. 
The measuring items of happiness are consistent with Chinese residents' perceptions of happiness, and they are easy to understand and answer (Bian et al. 2015). In addition, the total sample of this study consisted of $53.6 \%$ rural respondents. The vast majority of these received primary schooling or over six years of education. We therefore inferred that rural respondents could well comprehend the item on happiness and give an answer that fit their own reality. Given those reasons, the measurement of happiness that we employed was reliable.

\subsubsection{Measures of Religion}

According to the previous research, we gauged religion, the key variable in this study, according to two dimensions. First, we constructed a dichotomous measure via a survey question, and asked respondents whether they self-identified with "no religion" or "religion." For adherents, we further divided their religious identity into four categories: Buddhists, Muslims, Christians, and other religious faiths. Second, we adopted an ordinal scale to gauge the frequency of religious practices. Respondents selected from five ordered responses: never, less than once a year, several times per year, several times per month, and several times per week. Religious practices were just right for our study, since some literature used this approach and demonstrated that it exerted a stronger effect on people's subjective well-being (Sun and Zhang 2019).

\subsubsection{Measures of Other Variables}

We also considered some other factors that are related to happiness, religious affiliation, and religious practices. We controlled for respondents' demographic characteristics (i.e., age, ethnicity, marital status, and individual annual income). In the Chinese context, the characteristics at the individual level and family level are intertwined, and these may jointly influence this relationship between religion and happiness. Therefore, we controlled for individual factors (i.e., health condition, Chinese Communist Party (CCP), work status, subjective social status) and family factors (family annual income). In addition, we controlled for the individual social attitudes. Two items were used to measure social attitudes, including "In general, most people can be trusted in modern society" and "Generally speaking, do you think the current society is unfair?" For the first item, respondents were asked to indicate the extent of agreement ranging from (1) strongly disagree to (5) strongly agree. For the second item, they were asked to choose from a five-point scale ranging from (1) completely unfair to (5) completely fair.

Happiness, the key outcome variable of this study, was measured by an ordinal scale from 1 to 5. We therefore chose ordered logistic regression models to explain the relationship between religion and happiness. We found, however, that the models included in this study violated the parallel odds assumption tests. Finally, we used the generalized ordered logit models, and these were a more suitable approach (Williams 2005). The analysis proceeded with this study in two steps. First, we tested the relationship between different measurements of religion and happiness. For example, religious faith (dichotomized variable), different religious identities (Buddhists, Muslims, Christians, and other religious faiths), and the frequency of religious involvement. Second, we conducted a grouping of generalized ordered logit regression to test the heterogeneity of the influence of religion on happiness in different sub-samples.

\section{Results}

\subsection{Descriptive Analyses}

Table 1 displays the summary of statistics for the test variables of interest. As shown in Table 1 , approximately $79 \%$ of respondents admitted their lives were happy or very happy. Only about $6.8 \%$ reported their lives to be either unhappy or very unhappy. This percentage is the same as the findings from Europe and North America, where nearly $80 \%$ of people rated their feelings about their lives as more satisfied than unsatisfied (Myers 2000). Overall, the proportion of urban residents who felt 
their lives to be happy or very happy was larger than their rural counterparts. Meanwhile, about $21 \%$ of people living in the eastern areas perceived their lives to be very happy, but the percentage was just $13.5 \%$ in the western areas. Overall, $10.1 \%$ of the respondents identified themselves as religious believers, and the proportion of adherents was larger in the female and western areas sub-samples. Moreover, the number of Buddhists was the greatest of the four main religious believers (i.e., Buddhists, Muslims, Christians, and other religious faiths). Among the Buddhists, the proportion was largest in the female groups, with about 5.6\%. Most Muslims were women, whereas this proportion was small in the middle regions, and was far less than $0.5 \%$. The adherents living in the central areas were likely to be Christians. Christianity was not particularly prevalent among the people living in the western areas. We also found that rural residents, less-educated people, and ones from western regions were more likely to enjoy other religious faiths. More than $86 \%$ of survey respondents reported that they never participated in religious activities, and the proportion was relatively large in the sub-samples of the middle areas and higher-educated level, with $88.74 \%$ and $88.78 \%$, respectively. On the contrary, they tended to participate in religious activities an average of several times a year in the rural and western sub-samples. Three percent of women attended religious activities with greater frequency several times per week.

With respect to the grouped samples, the sample comprised 3768 females and 4114 males. The rural and urban samples were 4221 and 3661, respectively. Among them, the individual annual income of the rural residents and their family's annual income were far less than their urban counterparts, and the amount was only half of the latter's on average. We also divided the respondents' schooling years into two groups. One group consisted of 5110 individuals whose schooling years were fewer than or equal to nine years, while the other group comprised 2772 participants who received more than nine years education. The rate of unemployment in less-educated samples was larger than that of higher educated (37.59\% versus $27.81 \%$ ). Of the 7882 usable samples, there were 3216 eastern participants, 2761 central participants, and 1905 western participants. In terms of social attitudes, the residents from these three regions tended to trust and believe in social equity consistently. Meanwhile, the proportion of single people from the eastern regions was the highest compared with the other two areas $(9.92 \%$ versus $5.80 \%, 6.56 \%$ ). 
Table 1. The result of descriptive analyses (Mean/Percentage)

\begin{tabular}{|c|c|c|c|c|c|c|c|c|c|c|}
\hline Variables & Total & Women & Men & $\begin{array}{c}\text { Rural } \\
\text { Residents }\end{array}$ & $\begin{array}{c}\text { Urban } \\
\text { Residents }\end{array}$ & $\begin{array}{l}\text { Education } \\
\text { Years }(\leq 9)\end{array}$ & $\begin{array}{l}\text { Education } \\
\text { Years }(>9)\end{array}$ & $\begin{array}{c}\text { Living Area } \\
\text { (East) }\end{array}$ & $\begin{array}{c}\text { Living Area } \\
\text { (Middle) }\end{array}$ & $\begin{array}{c}\text { Living Area } \\
\text { (West) }\end{array}$ \\
\hline \multicolumn{11}{|l|}{ Happiness } \\
\hline Very unhappy & $1.07 \%$ & $1.19 \%$ & $0.95 \%$ & $1.33 \%$ & $0.76 \%$ & $1.37 \%$ & $0.74 \%$ & $0.37 \%$ & $1.27 \%$ & $1.94 \%$ \\
\hline Unhappy & $5.70 \%$ & $6.16 \%$ & $5.27 \%$ & $6.56 \%$ & $4.70 \%$ & $6.77 \%$ & $4.73 \%$ & $4.20 \%$ & $6.08 \%$ & $7.66 \%$ \\
\hline So-so & $14.56 \%$ & $13.77 \%$ & $15.29 \%$ & $15.54 \%$ & $13.44 \%$ & $15.56 \%$ & $13.67 \%$ & $13.50 \%$ & $13.80 \%$ & $17.48 \%$ \\
\hline Happy & $60.87 \%$ & $59.82 \%$ & $61.84 \%$ & $60.32 \%$ & $61.51 \%$ & $59.04 \%$ & $62.68 \%$ & $61.01 \%$ & $61.75 \%$ & $59.37 \%$ \\
\hline Very happy & $17.80 \%$ & $19.06 \%$ & $16.65 \%$ & $16.25 \%$ & $19.58 \%$ & $17.26 \%$ & $18.18 \%$ & $20.93 \%$ & $17.10 \%$ & $13.54 \%$ \\
\hline Religion affiliation (yes) & $10.11 \%$ & $12.31 \%$ & $8.09 \%$ & $10.66 \%$ & $9.48 \%$ & $11.45 \%$ & $7.65 \%$ & $10.17 \%$ & $8.11 \%$ & $12.91 \%$ \\
\hline Buddhists & $4.53 \%$ & $5.57 \%$ & $3.57 \%$ & $4.22 \%$ & $4.89 \%$ & $4.95 \%$ & $3.75 \%$ & $5.07 \%$ & $4.20 \%$ & $4.09 \%$ \\
\hline Muslims & $1.85 \%$ & $2.20 \%$ & $1.53 \%$ & $2.13 \%$ & $1.53 \%$ & $2.13 \%$ & $1.33 \%$ & $1.27 \%$ & $0.43 \%$ & $4.88 \%$ \\
\hline Christians & $1.87 \%$ & $2.63 \%$ & $1.17 \%$ & $1.92 \%$ & $1.80 \%$ & $1.96 \%$ & $1.70 \%$ & $1.68 \%$ & $2.79 \%$ & $0.84 \%$ \\
\hline Other religious faiths & $1.85 \%$ & $2.02 \%$ & $1.70 \%$ & $2.44 \%$ & $1.17 \%$ & $2.43 \%$ & $0.79 \%$ & $2.18 \%$ & $0.58 \%$ & $3.15 \%$ \\
\hline \multicolumn{11}{|l|}{ Frequency of religious participation } \\
\hline Never & $86.63 \%$ & $84.53 \%$ & $88.55 \%$ & $86.12 \%$ & $87.22 \%$ & $85.46 \%$ & $88.78 \%$ & $86.94 \%$ & $88.74 \%$ & $83.04 \%$ \\
\hline Less than once a year & $2.39 \%$ & $2.55 \%$ & $2.24 \%$ & $2.37 \%$ & $2.40 \%$ & $2.49 \%$ & $2.20 \%$ & $2.24 \%$ & $2.21 \%$ & $2.89 \%$ \\
\hline Several times per year & $7.22 \%$ & $7.86 \%$ & $6.64 \%$ & $7.82 \%$ & $6.53 \%$ & $7.71 \%$ & $6.31 \%$ & $6.53 \%$ & $5.83 \%$ & $10.39 \%$ \\
\hline Several times per month & $1.64 \%$ & $2.10 \%$ & $1.22 \%$ & $1.52 \%$ & $1.78 \%$ & $1.80 \%$ & $1.33 \%$ & $2.11 \%$ & $1.23 \%$ & $1.42 \%$ \\
\hline Several times per week & $2.13 \%$ & $2.97 \%$ & $1.36 \%$ & $2.18 \%$ & $2.08 \%$ & $2.54 \%$ & $1.37 \%$ & $2.18 \%$ & $1.99 \%$ & $2.26 \%$ \\
\hline \multicolumn{11}{|l|}{ Demographic Characteristics } \\
\hline Age & 55.06 & 55.14 & 54.99 & 53.68 & 56.65 & 58.39 & 48.93 & 54.81 & 55.04 & 55.52 \\
\hline Ethnicity (minority) & $7.23 \%$ & $7.32 \%$ & $7.15 \%$ & $9.36 \%$ & $4.78 \%$ & $8.32 \%$ & $5.23 \%$ & $3.36 \%$ & $4.64 \%$ & $17.53 \%$ \\
\hline \multicolumn{11}{|l|}{ Marital status } \\
\hline Single & $7.66 \%$ & $5.15 \%$ & $9.97 \%$ & $6.92 \%$ & $8.52 \%$ & $3.72 \%$ & $14.94 \%$ & $9.92 \%$ & $5.80 \%$ & $6.56 \%$ \\
\hline Married/cohabiting & $81.21 \%$ & $79.99 \%$ & $82.33 \%$ & $83.94 \%$ & $78.07 \%$ & $82.76 \%$ & $78.35 \%$ & $78.73 \%$ & $83.77 \%$ & $81.68 \%$ \\
\hline Divorced/widowed/Separated & $11.13 \%$ & $14.86 \%$ & $7.71 \%$ & $9.14 \%$ & $13.41 \%$ & $13.52 \%$ & $6.71 \%$ & $11.35 \%$ & $10.43 \%$ & $11.76 \%$ \\
\hline Individual annual Income (yuan) & 33,747 & 26,919 & 40,001 & 22,891 & 46,264 & 22,834 & 53,865 & 48,195 & 25,756 & 20,939 \\
\hline \multicolumn{11}{|l|}{ Individual Level } \\
\hline \multicolumn{11}{|l|}{ Health condition } \\
\hline Unhealthy & $16.15 \%$ & $18.02 \%$ & $14.44 \%$ & $18.57 \%$ & $13.36 \%$ & $20.59 \%$ & $7.97 \%$ & $11.91 \%$ & $17.57 \%$ & $21.26 \%$ \\
\hline So-so & $22.84 \%$ & $24.81 \%$ & $21.03 \%$ & $21.09 \%$ & $24.86 \%$ & $24.01 \%$ & $20.67 \%$ & $24.91 \%$ & $20.17 \%$ & $23.20 \%$ \\
\hline Healthy & $61.01 \%$ & $57.17 \%$ & $64.54 \%$ & $60.34 \%$ & $61.79 \%$ & $55.40 \%$ & $71.36 \%$ & $63.18 \%$ & $62.26 \%$ & $55.54 \%$ \\
\hline ССР (yes) & $12.23 \%$ & $7.25 \%$ & $16.80 \%$ & $4.95 \%$ & $20.62 \%$ & $6.30 \%$ & $23.16 \%$ & $16.23 \%$ & $10.32 \%$ & $8.24 \%$ \\
\hline \multicolumn{11}{|l|}{ Work status } \\
\hline Unemployed & $34.15 \%$ & $40.07 \%$ & $28.73 \%$ & $23.81 \%$ & $46.08 \%$ & $37.59 \%$ & $27.81 \%$ & $38.18 \%$ & $32.67 \%$ & $29.50 \%$ \\
\hline Employed & $65.85 \%$ & $59.93 \%$ & $71.27 \%$ & $76.19 \%$ & $53.92 \%$ & $62.41 \%$ & $72.19 \%$ & $61.82 \%$ & $67.33 \%$ & $70.50 \%$ \\
\hline Subjective social status & 2.48 & 2.51 & 2.46 & 2.36 & 2.63 & 2.39 & 2.66 & 2.61 & 2.42 & 2.37 \\
\hline \multicolumn{11}{|l|}{ Family Level } \\
\hline Family annual Income (yuan) & 64,757 & 61,919 & 67,356 & 45,712 & 86,715 & 45,750 & 99,794 & 91,332 & 50,079 & 41,166 \\
\hline \multicolumn{11}{|l|}{ Social Attitudes } \\
\hline Trust in most people & 3.51 & 3.49 & 3.53 & 3.55 & 3.46 & 3.52 & 3.49 & 3.48 & 3.52 & 3.52 \\
\hline Perceived social equity & 2.24 & 2.23 & 2.25 & 2.27 & 2.20 & 2.26 & 2.20 & 2.18 & 2.27 & 2.29 \\
\hline $\mathrm{N}$ & 7882 & 3768 & 4114 & 4221 & 3661 & 5110 & 2772 & 3216 & 2761 & 1905 \\
\hline
\end{tabular}




\subsection{The Relationship between Religion and Happiness}

Table 2 presents the regression results regarding the relationship between religion and happiness in total samples. First, the sets of control variables and religious affiliation, a dummy variable, were entered into Model 1, and the regression results indicated that people with religious faith rated themselves higher on the happiness scale. Specifically, holding for all the control variables, religious adherents had 0.46 times higher odds than nonreligious of feeling happy to very happy. Second, we further investigated the denominational differences in happiness. As shown in Model 2, we found that Buddhists had 0.25 times higher odds of feeling very happy than non-Buddhists. Interestingly, Muslims were less likely to be unhappy than non-Muslims. In other words, Muslims were likely to feel a higher level of happiness than were non-Muslims. Meanwhile, the results of Model 4 showed that people of the Christian faith did not rate themselves higher on the happiness scale, but they had about 0.73 times higher odds of being unhappy than non-Christians. According to Model 5, we argued that people with religious beliefs other than Buddhism, Christianity, and Catholicism were more likely to be very happy than nonreligious people. The results revealed that religious involvement was significantly correlated with happiness, which meant that if a person increased the frequency of religious participation by one unit, the probability of him or her being happy to being very happy would rise by about 0.11 times.

\subsection{The Influence of Religion on Happiness in Different Groups}

As discussed in Section 3, some cultural and economic contexts (i.e., gender, years of education, and region) tended to yield different effects on this relationship between religion and happiness. To test these propositions, the total samples were divided into nine sub-samples, judging by the factors mentioned above. Table 3 shows the influence of religious belief on happiness in different sub-samples. As shown in Table 3, we first examined the difference in the effect of religious belief on happiness between men and women (see Model 1 and Model 2). The results revealed that religious affiliations significantly predicted happiness in both male and female groups. Specifically, if a man had a religious belief, he was about $5.6 \%$ more likely to feel very happy than a nonreligious person. This figure was only $3.3 \%$ in the female groups. The interesting finding was that political status (i.e., membership in the Chinese Communist Party) played a positive role in male happiness, but no evidence supported this conclusion in the female group. We secondly suggested that believers had about 0.66 times higher odds of feeling very happy than nonreligious believers in rural areas, whereas this positive relationship did not exist in the urban samples. 
Table 2. The results of generalized ordered logit regression.

\begin{tabular}{|c|c|c|c|c|c|c|c|}
\hline Happiness & Variables & Model 1 & Model 2 & Model 3 & Model 4 & Model 5 & Model 6 \\
\hline \multirow{6}{*}{ Very unhappy } & Religious affiliation & $\begin{array}{c}0.128 \\
(0.353)\end{array}$ & & & \multirow{6}{*}{$\begin{array}{c}0.902 \\
(0.882)\end{array}$} & & \\
\hline & Buddhists & & $\begin{array}{c}0.302 \\
(0.498)\end{array}$ & & & & \\
\hline & Muslims & & & $\begin{array}{l}-1.726^{* *} \\
(-2.037)\end{array}$ & & & \\
\hline & Christians & & & & & & \\
\hline & Other religious faiths & & & & & $\begin{array}{l}13.621 \\
(0.021)\end{array}$ & \\
\hline & Frequency of religious participation & & & & & & $\begin{array}{c}-0.054 \\
(-0.465)\end{array}$ \\
\hline \multirow{6}{*}{ Unhappy } & Religious affiliation & $\begin{array}{c}0.449^{* * *} \\
(2.646)\end{array}$ & & & \multirow{6}{*}{$\begin{array}{l}0.726^{*} \\
(1.772)\end{array}$} & & \\
\hline & Buddhists & & $\begin{array}{c}0.406 \\
(1.588)\end{array}$ & & & & \\
\hline & Muslims & & & $\begin{array}{c}0.320 \\
(0.859)\end{array}$ & & & \\
\hline & Christians & & & & & & \\
\hline & Other religious faiths & & & & & $\begin{array}{c}0.271 \\
(0.752)\end{array}$ & \\
\hline & Frequency of religious participation & & & & & & $\begin{array}{l}0.105 * \\
(1.756)\end{array}$ \\
\hline \multirow{6}{*}{ So-so } & Religious affiliation & $\begin{array}{c}0.342^{* * *} \\
(3.241)\end{array}$ & & & \multirow{6}{*}{$\begin{array}{c}0.354 \\
(1.508)\end{array}$} & & \\
\hline & Buddhists & & $\begin{array}{l}0.261 \text { * } \\
(1.752)\end{array}$ & & & & \\
\hline & Muslims & & & $\begin{array}{l}0.624^{* *} \\
(2.344)\end{array}$ & & & \\
\hline & Christians & & & & & \multirow{3}{*}{$\begin{array}{c}0.059 \\
(0.275)\end{array}$} & \\
\hline & Other religious faiths & & & & & & \\
\hline & Frequency of religious participation & & & & & & $\begin{array}{l}0.079 * * \\
(2.095)\end{array}$ \\
\hline
\end{tabular}


Table 2. Cont.

\begin{tabular}{|c|c|c|c|c|c|c|c|}
\hline Happiness & Variables & Model 1 & Model 2 & Model 3 & Model 4 & Model 5 & Model 6 \\
\hline \multirow{6}{*}{ Happy } & Religious affiliation & $\begin{array}{c}0.458^{* * *} \\
(4.749)\end{array}$ & & & & & \\
\hline & Buddhists & & $\begin{array}{l}0.249 * \\
(1.810)\end{array}$ & & & & \\
\hline & Muslims & & & $\begin{array}{c}1.032 * * * \\
(4.347)\end{array}$ & & & \\
\hline & Christians & & & & $\begin{array}{c}0.341 \\
(1.632)\end{array}$ & \multirow{3}{*}{$\begin{array}{l}0.382 * \\
(1.842)\end{array}$} & \\
\hline & Other religious faiths & & & & & & \multirow[b]{2}{*}{$\begin{array}{r}0.107^{* * *} \\
(3.117)\end{array}$} \\
\hline & Frequency of religious participation & & & & & & \\
\hline & $\mathrm{N}$ & 7882 & 7882 & 7882 & 7882 & 7882 & 7882 \\
\hline & Pseudo $\mathrm{R}^{2}$ & 0.096 & 0.095 & 0.096 & 0.095 & 0.095 & 0.095 \\
\hline & LR chi ${ }^{2}$ & 1669.07 & 1645.57 & 1667.50 & 1645.48 & 1646.20 & 1653.31 \\
\hline
\end{tabular}

Note: (1) t statistics in parentheses, ${ }^{*} p<0.1,{ }^{* *} p<0.05,{ }^{* * *} p<0.01$; (2) For simplicity, the regression results of some representative control variables are presented (i.e., individual annual income, CCP, and subjective social status), and the rest of the control variables are controlled. 
Table 3. The results of the influence of religious belief on happiness in different groups.

\begin{tabular}{|c|c|c|c|c|c|c|c|c|c|c|}
\hline \multirow{2}{*}{ Happiness } & \multirow{2}{*}{ Variables/Groups } & Model 1 & Model 2 & Model 3 & Model 4 & Model 5 & Model 6 & Model 7 & Model 8 & Model 9 \\
\hline & & Women & Men & $\begin{array}{c}\text { Rural } \\
\text { Residents }\end{array}$ & $\begin{array}{c}\text { Urban } \\
\text { Residents }\end{array}$ & $\begin{array}{l}\text { Education } \\
\text { Years }(\leq 9)\end{array}$ & $\begin{array}{l}\text { Education } \\
\text { Years }(>9)\end{array}$ & $\begin{array}{l}\text { Living Area } \\
\text { (East) }\end{array}$ & $\begin{array}{l}\text { Living Area } \\
\text { (Middle) }\end{array}$ & $\begin{array}{l}\text { Living Area } \\
\text { (West) }\end{array}$ \\
\hline \multirow{5}{*}{$\begin{array}{c}\text { Very } \\
\text { unhappy }\end{array}$} & Religious affiliation & $\begin{array}{c}0.244 \\
(0.508)\end{array}$ & $\begin{array}{c}-0.541 \\
(-0.847)\end{array}$ & $\begin{array}{c}0.475 \\
(0.954)\end{array}$ & $\begin{array}{c}-0.392 \\
(-0.660)\end{array}$ & $\begin{array}{c}0.101 \\
(0.264)\end{array}$ & $\begin{array}{c}-0.091 \\
(-0.081)\end{array}$ & $\begin{array}{c}-0.240 \\
(-0.211)\end{array}$ & $\begin{array}{c}0.526 \\
(0.813)\end{array}$ & $\begin{array}{c}0.126 \\
(0.218)\end{array}$ \\
\hline & $\begin{array}{l}\text { Log (Individual annual } \\
\text { Income) }\end{array}$ & $\begin{array}{c}0.110 \\
(0.600)\end{array}$ & $\begin{array}{l}-0.064 \\
(-0.279)\end{array}$ & $\begin{array}{c}0.028 \\
(0.165)\end{array}$ & $\begin{array}{l}0.353 \\
(1.364)\end{array}$ & $\begin{array}{c}0.110 \\
(0.769)\end{array}$ & $\begin{array}{l}0.112 \\
(0.226)\end{array}$ & $\begin{array}{l}-0.685 \\
(-1.181)\end{array}$ & $\begin{array}{l}-0.042 \\
(-0.203)\end{array}$ & $\begin{array}{c}0.209 \\
(0.989)\end{array}$ \\
\hline & & 0.902 & 0.593 & -0.608 & 1.186 & 0.050 & 1.413 & 0.151 & 13.311 & 0.038 \\
\hline & $\mathrm{CCP}$ & $(0.868)$ & $(0.975)$ & $(-0.977)$ & $(1.142)$ & $(0.082)$ & $(1.306)$ & $(0.176)$ & $(0.028)$ & $(0.051)$ \\
\hline & Subjective social status & $\begin{array}{c}0.820^{* * *} \\
(3.754)\end{array}$ & $\begin{array}{c}1.315^{* * *} \\
(5.110)\end{array}$ & $\begin{array}{c}0.682 * * * \\
(3.408)\end{array}$ & $\begin{array}{c}1.605 * * * \\
(5.059)\end{array}$ & $\begin{array}{c}1.181 * * * \\
(6.242)\end{array}$ & $\begin{array}{c}0.338 \\
(0.970)\end{array}$ & $\begin{array}{c}1.855^{* * *} \\
(3.384)\end{array}$ & $\begin{array}{c}0.971^{* * *} \\
(3.648)\end{array}$ & $\begin{array}{c}0.918^{* * *} \\
(3.642)\end{array}$ \\
\hline \multirow{6}{*}{ Unhappy } & Religious affiliation & $\begin{array}{l}0.150 \\
0727)\end{array}$ & $1.032^{* * *}$ & $0.677^{* * *}$ & 0.183 & $0.421 * *$ & 0.751 & 0.530 & 0.364 & 0.425 \\
\hline & Log (Individual annual & -0.041 & 0.010 & -0.022 & 0.084 & 0.021 & -0.165 & -0.152 & -0.063 & 0.118 \\
\hline & Income) & $(-0.524)$ & $(0.096)$ & $(-0.301)$ & $(0.676)$ & $(0.318)$ & $(-1.013)$ & $(-1.264)$ & $(-0.648)$ & (1.176) \\
\hline & ССР & $0.817^{*}$ & 0.162 & -0.138 & $0.486^{*}$ & -0.014 & 0.437 & 0.360 & $0.651 *$ & 0.100 \\
\hline & & $(1.878)$ & $(0.751)$ & $(-0.456)$ & $(1.944)$ & $(-0.052)$ & $(1.538)$ & $(1.227)$ & $(1.696)$ & $(0.304)$ \\
\hline & Subjective social status & $\begin{array}{c}0.602 * * * \\
(7.004)\end{array}$ & $\begin{array}{c}0.736^{* * *} \\
(8.218)\end{array}$ & $\begin{array}{c}0.603 * * * \\
(7.632)\end{array}$ & $\begin{array}{c}0.739 * * * \\
(7.465)\end{array}$ & $\begin{array}{c}0.654 * * * \\
(9.148)\end{array}$ & $\begin{array}{c}0.684^{* * *} \\
(5.513)\end{array}$ & $\begin{array}{c}0.944^{* * *} \\
(8.298)\end{array}$ & $\begin{array}{c}0.582 * * * \\
(5.752)\end{array}$ & $\begin{array}{c}0.463 * * * \\
(4.101)\end{array}$ \\
\hline \multirow{5}{*}{ So-so } & Religious affiliation & $\begin{array}{c}0.135 \\
(0.972)\end{array}$ & $\begin{array}{c}0.580 * * * \\
(3.513)\end{array}$ & $\begin{array}{c}0.384^{* * *} \\
(2.810)\end{array}$ & $\begin{array}{l}0.282 * \\
(1.702)\end{array}$ & $\begin{array}{c}0.433 * * * \\
(3.537)\end{array}$ & $\begin{array}{c}0.065 \\
(0.315)\end{array}$ & $\begin{array}{c}0.253 \\
(1.460)\end{array}$ & $\begin{array}{c}0.268 \\
(1.411)\end{array}$ & $\begin{array}{c}0.566^{* * *} \\
(2.921)\end{array}$ \\
\hline & Log (Individual annual & $-0.162 * * *$ & 0.034 & -0.043 & -0.128 & -0.032 & $-0.285^{* * *}$ & $-0.221 * * *$ & -0.083 & 0.015 \\
\hline & & $0.602 * * *$ & $0.459^{* * * *}$ & 0.288 & $0.563 * * *$ & 0.211 & $0.647^{* * *}$ & $0.522 * * *$ & $\begin{array}{c}(-1.316) \\
0.243\end{array}$ & $\begin{array}{l}(0.216) \\
0.658 * *\end{array}$ \\
\hline & ССР & $(2.620)$ & $(3.444)$ & $(1.376)$ & $(4.078)$ & $(1.241)$ & $(4.089)$ & $(3.162)$ & $(1.212)$ & $(2.570)$ \\
\hline & Subjective social status & $\begin{array}{l}0.579 * * * \\
(10.206)\end{array}$ & $\begin{array}{c}0.506^{* * *} \\
(9.598)\end{array}$ & $\begin{array}{l}0.529 * * * \\
(10.503)\end{array}$ & $\begin{array}{c}0.570 * * * \\
(9.493)\end{array}$ & $\begin{array}{l}0.570 * * * \\
(12.362)\end{array}$ & $\begin{array}{c}0.471^{* * *} \\
(6.643)\end{array}$ & $\begin{array}{c}0.499^{* * *} \\
(7.913)\end{array}$ & $\begin{array}{c}0.631^{* * *} \\
(9.687)\end{array}$ & $\begin{array}{c}0.516^{* * *} \\
(6.918)\end{array}$ \\
\hline \multirow{8}{*}{ Happy } & Religious affiliation & $\begin{array}{c}0.333^{* * *} \\
(2.592)\end{array}$ & $\begin{array}{c}0.561^{* * *} \\
(3.805)\end{array}$ & $\begin{array}{c}0.662 * * * \\
(5.040)\end{array}$ & $\begin{array}{c}0.228 \\
(1.591)\end{array}$ & $\begin{array}{c}0.527^{* * *} \\
(4.585)\end{array}$ & $\begin{array}{l}0.299 * \\
(1.659)\end{array}$ & $\begin{array}{c}0.150 \\
(1.028)\end{array}$ & $\begin{array}{l}0.370 * * \\
(2.029)\end{array}$ & $\begin{array}{c}1.064^{* * *} \\
(5.451)\end{array}$ \\
\hline & Log (Individual annual & -0.060 & $\begin{array}{c}0.025 \\
(0.414)\end{array}$ & $\begin{array}{l}-0.023 \\
(-0.490)\end{array}$ & $\begin{array}{l}-0.067 \\
(-0.972)\end{array}$ & 0.030 & $-0.205^{* * *}$ & -0.043 & -0.035 & $-0.185^{* *}$ \\
\hline & Income) & $(-1.247)$ & $(0.414)$ & $(-0.490)$ & $(-0.972)$ & $(0.695)$ & $(-2.734)$ & $(-0.711)$ & $(-0.580)$ & $(-2.475)$ \\
\hline & $\mathrm{CCP}$ & $\begin{array}{l}0.304^{* *} \\
(2.010)\end{array}$ & $\begin{array}{c}0.097 \\
(0.846)\end{array}$ & $\begin{array}{c}0.067 \\
(0.366)\end{array}$ & $\begin{array}{c}0.105 \\
(0.994)\end{array}$ & $\begin{array}{c}0.131 \\
(0.893)\end{array}$ & $\begin{array}{c}0.172 \\
(1.445)\end{array}$ & $\begin{array}{c}0.080 \\
(0.666)\end{array}$ & $\begin{array}{c}0.058 \\
(0.344)\end{array}$ & $\begin{array}{c}0.079 \\
(0.339)\end{array}$ \\
\hline & Subjective social status & $\begin{array}{c}0.520^{* * *} \\
(8.691)\end{array}$ & $\begin{array}{c}0.223^{* * *} \\
(3.974)\end{array}$ & $\begin{array}{l}0.388^{* * *} \\
(7.014)\end{array}$ & $\begin{array}{c}0.351^{* * * *} \\
(5.836)\end{array}$ & $\begin{array}{c}0.400^{* * *} \\
(7.959)\end{array}$ & $\begin{array}{c}0.339^{* * *} \\
(4.824)\end{array}$ & $\begin{array}{c}0.369^{* * *} \\
(5.981)\end{array}$ & $\begin{array}{c}0.363^{* * *} \\
(5.304)\end{array}$ & $\begin{array}{c}0.392^{* * *} \\
(4.393)\end{array}$ \\
\hline & $\mathrm{N}$ & 3768 & 4114 & 4221 & 3661 & 5110 & 2772 & 3216 & 2761 & 1905 \\
\hline & Pseudo $\mathrm{R}^{2}$ & 0.110 & 0.092 & 0.096 & 0.100 & 0.100 & 0.092 & 0.089 & 0.098 & 0.123 \\
\hline & LR chi ${ }^{2}$ & 926.01 & 821.80 & 915.56 & 778.41 & 1174.26 & 514.40 & 601.13 & 597.26 & 541.79 \\
\hline
\end{tabular}

Note: (1) t statistics in parentheses, ${ }^{*} p<0.1,{ }^{* *} p<0.05,{ }^{* * *} p<0.01$; (2) For simplicity, the regression results of some representative control variables are presented (i.e., individual annual income, CCP, and subjective social status), and the rest of the control variables are controlled. 
We next tested the relationship between religious affiliation and happiness in lesser- and higher-educated groups (see Model 5 and Model 6 in Table 3). Contrary to our expectation, the positive association between them still existed in both sub-samples, but there were differences in the significance level and the regression coefficient between them. Specifically, in terms of lesser-educated people with religious faith, they had 0.53 times higher odds of feeling very happy, and the proportion was about 3.0\% for higher educational attainment groups. Meanwhile, the significance level of the higher-educated groups was less than their low counterparts, with 0.1 and 0.01 , respectively. It was interesting to note that the probability of feeling very happy tended to decrease in higher-educated groups as individual annual income increased. This result suggested that China also has fallen into the happiness-income paradox, which was consistent with some developed countries (Easterlin et al. 2010).

Finally, we analyzed whether the relationship between religious belief and religion varied in the eastern, central, and western regions of China. Among the three areas, the odds of religious believers feeling very happy was about $10.6 \%$ in the western regions (see Model 9 ), and this figure was only $3.7 \%$ in the middle regions (see Model 8). However, as shown in Table 3, Model 7 showed no evidence indicating the same result could happen in the eastern areas.

Table 4 reports the results of religious participation influencing happiness by different sub-samples. As shown in Model 1 and Model 2 in Table 4, we found that men had 0.16 times higher odds of feeling happy to very happy as their frequency of participating in religious activities increased. However, this connection did not exist in the female samples. This finding of our paper was consistent with the conclusions of previous studies (Wei and Liu 2013). Meanwhile, according to the results of Model 3 and Model 4, it was obvious that the rural residents' religious involvement helped them feel very happy $(\beta=0.153, p<0.01)$, whereas this had no effect on urban residents' happiness. The results of Model 5 and Model 6 indicated that this significant and positive relationship also existed in the samples of lower education $(\beta=0.138, p<0.01)$, but for highly educated people, religious participation was unrelated to their happiness. In addition, attendance at religious services was not correlated with happiness for the residents of middle and eastern regions, and only those living in western areas had greater odds of perceiving themselves as very happy from continual religious practices $(\beta=0.250$, $p<0.01$ ). In summary, we reasoned that the participation in religious activities had a greater positive significance for vulnerable groups' happiness. 
Table 4. The results of the influence of religious participation on happiness in different groups.

\begin{tabular}{|c|c|c|c|c|c|c|c|c|c|c|}
\hline \multirow{2}{*}{ Happiness } & \multirow{2}{*}{ Variables/Groups } & Model 1 & Model 2 & Model 3 & Model 4 & Model 5 & Model 6 & Model 7 & Model 8 & Model 9 \\
\hline & & Women & Men & $\begin{array}{c}\text { Rural } \\
\text { Residents }\end{array}$ & $\begin{array}{c}\text { Urban } \\
\text { Residents }\end{array}$ & $\begin{array}{l}\text { Education } \\
\text { Years }(\leq 9)\end{array}$ & $\begin{array}{l}\text { Education } \\
\text { Years }(>9)\end{array}$ & $\begin{array}{l}\text { Living Area } \\
\text { (East) }\end{array}$ & $\begin{array}{l}\text { Living Area } \\
\text { (Middle) }\end{array}$ & $\begin{array}{l}\text { Living Area } \\
\text { (West) }\end{array}$ \\
\hline \multirow{6}{*}{$\begin{array}{c}\text { Very } \\
\text { unhappy }\end{array}$} & $\begin{array}{l}\text { Frequency of religious } \\
\text { participation }\end{array}$ & $\begin{array}{c}0.149 \\
(0.861)\end{array}$ & $\begin{array}{l}-0.568^{* * *} \\
(-2.741)\end{array}$ & $\begin{array}{c}0.024 \\
(0.157)\end{array}$ & $\begin{array}{l}-0.204 \\
(-1.092)\end{array}$ & $\begin{array}{l}-0.088 \\
(-0.736)\end{array}$ & $\begin{array}{c}0.220 \\
(0.392)\end{array}$ & $\begin{array}{l}-0.283 \\
(-0.838)\end{array}$ & $\begin{array}{c}0.253 \\
(0.943)\end{array}$ & $\begin{array}{c}-0.271 \\
(-1.431)\end{array}$ \\
\hline & Log (Individual annual & 0.110 & 0.010 & 0.031 & 0.346 & 0.122 & 0.116 & -0.730 & -0.044 & 0.286 \\
\hline & Income) & $(0.598)$ & $(0.038)$ & $(0.182)$ & (1.332) & $(0.849)$ & $(0.237)$ & $(-1.257)$ & $(-0.214)$ & (1.334) \\
\hline & СCP & $\begin{array}{c}0.909 \\
(0.875)\end{array}$ & $\begin{array}{c}0.464 \\
(0.761)\end{array}$ & $\begin{array}{l}-0.616 \\
(-0.992)\end{array}$ & $\begin{array}{c}1.201 \\
(1.161)\end{array}$ & $\begin{array}{c}0.022 \\
(0.036)\end{array}$ & $\begin{array}{c}1.424 \\
(1.314)\end{array}$ & $\begin{array}{c}0.121 \\
(0.139)\end{array}$ & $\begin{array}{l}13.221 \\
(0.028)\end{array}$ & $\begin{array}{c}0.004 \\
(0.005)\end{array}$ \\
\hline & & $0.814^{* * *}$ & $1.341^{* * *}$ & $0.689^{* * *}$ & $1.621^{* * *}$ & $1.189^{* * *}$ & 0.354 & $1.918^{* * *}$ & $0.951^{* * *}$ & $0.893^{* * *}$ \\
\hline & Subjective social status & $(3.734)$ & $(5.344)$ & $(3.433)$ & $(5.075)$ & $(6.261)$ & (1.027) & $(3.320)$ & $(3.576)$ & $(3.521)$ \\
\hline \multirow{7}{*}{ Unhappy } & Frequency of religious & 0.061 & 0.181 * & $0.159^{* *}$ & 0.023 & 0.077 & 0.219 & 0.117 & 0.134 & 0.050 \\
\hline & participation & $(0.803)$ & $(1.808)$ & (2.103) & $(0.242)$ & (1.197) & $(1.288)$ & $(0.994)$ & $(1.289)$ & $(0.490)$ \\
\hline & Log (Individual annual & -0.041 & 0.005 & -0.029 & 0.080 & 0.019 & -0.155 & -0.147 & -0.067 & 0.114 \\
\hline & Income) & $(-0.533)$ & $(0.050)$ & $(-0.395)$ & $(0.645)$ & $(0.291)$ & $(-0.958)$ & $(-1.202)$ & $(-0.690)$ & (1.126) \\
\hline & CCP & $0.809 *$ & 0.150 & -0.134 & $0.477^{*}$ & -0.024 & 0.426 & 0.360 & 0.618 & 0.095 \\
\hline & $C C P$ & $(1.860)$ & $(0.698)$ & $(-0.442)$ & (1.914) & $(-0.090)$ & (1.497) & $(1.226)$ & $(1.610)$ & $(0.290)$ \\
\hline & Subjective social status & $\begin{array}{c}0.601 * * * \\
(6.996)\end{array}$ & $\begin{array}{c}0.724^{* * *} \\
(8.103)\end{array}$ & $\begin{array}{c}0.605^{* * *} \\
(7.648)\end{array}$ & $\begin{array}{c}0.737^{* * *} \\
(7.472)\end{array}$ & $\begin{array}{l}0.654^{* * *} \\
(9.151)\end{array}$ & $\begin{array}{l}0.673^{* * * *} \\
(5.454)\end{array}$ & $\begin{array}{l}0.942^{* * *} \\
(8.267)\end{array}$ & $\begin{array}{l}0.576^{* * *} \\
(5.718)\end{array}$ & $\begin{array}{c}0.463^{* * *} \\
(4.148)\end{array}$ \\
\hline \multirow{7}{*}{ So-so } & Frequency of religious & 0.054 & $0.102 *$ & $0.090 *$ & 0.059 & $0.087^{* *}$ & 0.053 & 0.090 & 0.034 & 0.110 \\
\hline & participation & $(1.062)$ & (1.794) & $(1.827)$ & $(1.016)$ & (1.995) & $(0.699)$ & $(1.398)$ & $(0.514)$ & $(1.575)$ \\
\hline & Log (Individual annual & $-0.162 * * *$ & 0.036 & -0.044 & -0.127 & -0.033 & $-0.282 * * *$ & $-0.214^{* * *}$ & -0.084 & 0.006 \\
\hline & Income) & $(-3.016)$ & $(0.623)$ & $(-0.961)$ & $(-1.627)$ & $(-0.783)$ & $(-3.065)$ & $(-2.934)$ & $(-1.336)$ & $(0.084)$ \\
\hline & СCP & $0.598^{* * * *}$ & $0.447^{* * *}$ & 0.288 & $0.551^{* * *}$ & 0.199 & $0.648 * * *$ & $0.518 * * *$ & 0.230 & $0.660^{* * *}$ \\
\hline & $C P^{\prime}$ & $(2.605)$ & $(3.360)$ & (1.378) & $(4.003)$ & (1.175) & $(4.100)$ & (3.144) & (1.152) & $(2.581)$ \\
\hline & Subjective social status & $\begin{array}{l}0.579^{* * *} \\
(10.201)\end{array}$ & $\begin{array}{l}0.501 * * * \\
(9.548)\end{array}$ & $\begin{array}{l}0.530^{* * *} \\
(10.541)\end{array}$ & $\begin{array}{l}0.568^{* * *} \\
(9.470)\end{array}$ & $\begin{array}{l}0.569^{* * *} \\
(12.363)\end{array}$ & $\begin{array}{c}0.471^{* * *} \\
(6.642)\end{array}$ & $\begin{array}{l}0.499^{* * *} \\
(7.914)\end{array}$ & $\begin{array}{l}0.630^{* * *} \\
(9.667)\end{array}$ & $\begin{array}{l}0.515^{* * *} \\
(6.923)\end{array}$ \\
\hline \multirow{10}{*}{ Happy } & Frequency of religious & 0.057 & $0.155^{* * *}$ & $0.153^{* * *}$ & 0.069 & $0.138^{* * *}$ & 0.041 & 0.059 & 0.068 & $0.250^{* * *}$ \\
\hline & participation & $(1.258)$ & $(2.876)$ & (3.143) & $(1.394)$ & (3.359) & $(0.633)$ & $(1.172)$ & $(1.079)$ & $(3.286)$ \\
\hline & Log (Individual annual & -0.063 & 0.028 & -0.022 & -0.067 & 0.029 & $-0.204^{* * *}$ & -0.041 & -0.036 & $-0.196 * * *$ \\
\hline & Income) & $(-1.291)$ & $(0.461)$ & $(-0.463)$ & $(-0.980)$ & $(0.672)$ & $(-2.719)$ & $(-0.670)$ & $(-0.595)$ & $(-2.635)$ \\
\hline & & $0.289 *$ & 0.087 & 0.057 & 0.101 & 0.116 & 0.160 & 0.081 & 0.042 & 0.080 \\
\hline & ССР & $(1.915)$ & $(0.763)$ & $(0.309)$ & $(0.961)$ & $(0.795)$ & (1.347) & $(0.674)$ & $(0.250)$ & $(0.345)$ \\
\hline & Subjective social status & $\begin{array}{l}0.522 * * * \\
(8.733)\end{array}$ & $\begin{array}{l}0.225^{* * *} \\
(4.000)\end{array}$ & $\begin{array}{l}0.393 * * * \\
(7.110)\end{array}$ & $\begin{array}{l}0.351^{* * *} \\
(5.831)\end{array}$ & $\begin{array}{l}0.401^{* * * *} \\
(7.997)\end{array}$ & $\begin{array}{l}0.342 * * * \\
(4.857)\end{array}$ & $\begin{array}{c}0.369^{* * *} \\
(5.988)\end{array}$ & $\begin{array}{l}0.361^{* * *} \\
(5.274)\end{array}$ & $\begin{array}{l}0.409 * * * \\
(4.580)\end{array}$ \\
\hline & $\mathrm{N}$ & 3768 & 4114 & 4221 & 3661 & 5110 & 2772 & 3216 & 2761 & 1905 \\
\hline & Pseudo $R^{2}$ & 0.109 & 0.091 & 0.094 & 0.099 & 0.099 & 0.091 & 0.089 & 0.098 & 0.119 \\
\hline & LR chi ${ }^{2}$ & 921.95 & 811.56 & 896.98 & 776.96 & 1160.04 & 511.02 & 600.75 & 594.76 & 524.29 \\
\hline
\end{tabular}

Note: (1) $\mathrm{t}$ statistics in parentheses, ${ }^{*} p<0.1,{ }^{* *} p<0.05,{ }^{* * *} p<0.01$; (2) For simplicity, the regression results of some representative control variables are presented (i.e., individual annual income, $\mathrm{CCP}$, and subjective social status), and the rest of the control variables are controlled. 


\section{Discussion}

China, as the world's largest country of religious freedom, is ruled by an atheist party, which is different from other countries, such as the United States. Thus, a study about the religious problems of China has great significance for perceiving the diversity of the world religions. However, empirical research on the influence of religion in the field of happiness is still relatively limited in China. In addition, few studies have focused on the differences in the influence of religion on happiness in the Chinese special cultural and economic context (i.e., hukou, different education levels, and regions with imbalanced economic development). In view of this, we adopted the social support theory to examine the influence of religion on happiness and to further analyze whether the influence was varied among different groups. The findings of this study revealed that religious belief and religious participation are significantly associated with happiness. This conclusion is completely consistent with the results of considerable empirical research in the west (Francis et al. 2004; Levin 2011). Meanwhile, Muslims are more likely to feel very happy when compared to non-Muslims, whereas people of the Christian faith do not rate themselves higher on the happiness scale than non-Christians. This may be because there are so many formal or informal social restrictions imposed on Christians in China that the negative consequences of the Christian identity outweigh the possible positive effect on happiness (Hu et al. 2017).

More importantly, the results revealed the disadvantaged groups (i.e., rural residents, some people living in the western regions with lower levels of economic development, lesser-educated groups) are more likely to feel happy by religious practices. This is because the disadvantaged groups generally lack a sense of security and social security and often feel pressure and risk from various aspects, such as income fluctuations and health. Concurrently, their daily cultural life and entertainment activities are relatively poor. This is because the public spaces and basic facilities that could meet the recreational needs of all the vulnerable groups are in short supply. From the perspective of the social support theory, frequent religious involvement creates a platform for them to communicate and exchange their goods, information, and services. They can enjoy larger and denser social networks and have access to social support among their members (Stark and Liu 2011; Chatters 2000) by regular attendance at religious activities. Religious involvement becomes an important mechanism for them to deal with stress and risks (Dehejia et al. 2007). Hence, they are more likely to gain higher happiness from religious participation. This conclusion is consistent with existing research. For example, studies by Ellison (1991) showed that religious participation is positively related to happiness, especially for persons with low levels of formal education. With respect to the remaining five sub-samples, their social and economic status is relatively high, and they usually have many channels to receive social support. We infer that they can easily cope with some stress and risks, and there are more opportunities for them to take part in recreational activities. Therefore, the positive effects of participation in religious activities are limited for them and will not have an impact on their happiness.

The interesting finding was that the positive relationship between religious participation and happiness is not significant in female groups, but it exists in male groups. In general, the male dominates the domestic life and marital relationships in Chinese society. The female is required to meet their obligations, including taking good care of their husband and children, and these duties occupy most of their spare time. They therefore do not have enough of their own time to participate in social activities outside the home. If they attend religious practices frequently, this could exert a negative effect on the performance of their obligations, easily triggering family and marriage conflicts (Wei and Liu 2013). In addition, men often play an important role in religious activities, while women tend to undertake auxiliary tasks such as cooking, cleaning the church, etc. (McFarland 2010). Thus, religious participation is not more likely to bring on happiness for females, but it plays a positive role in increasing male happiness. According to the present reality in China, this problem is still prevalent in rural areas. This is because, compared with her urban counterpart, the average rural female is less educated and not financially independent, and thus more likely to rely on her husband to live. In 
summary, we can go further and indicate that the positive effect of religious participation on happiness does not exist for rural females.

Given the positive effects of religious faiths and religious attendance, this study has some practical implications. On the one hand, the government and other relevant management should consistently improve the policy on freedom of religious belief and guide the public to participate in various religious activities reasonably and compliantly, in order to expand social networks and improve public happiness (Lim and Putnam 2010). On the other hand, from the perspective of academic research, more attention should be paid to the development of religion and its influence within the unique cultural situation in China. Future studies can further explore the specific mediating mechanism of the influence of religion on happiness and the boundary conditions under which it plays its role.

This study has its limitations. First, we employed the cross-section data to study the relationship between religion and happiness in the Chinese context. This depicted the relationship between these two variables only at the node in 2015.Our research has not yet answered whether this relationship has changed over time. This is because the CGSS is not tracking the data, and the respondents are different in every wave. In further studies, we will attempt to adopt the panel data to examine the changing trend of this relationship, and use different data sets to compare our findings, i.e., the World Value Survey and China Family Panel Studies. Second, when measuring the frequency of participation in religious activities, because the questionnaire did not define which activities are religious activities, respondents answered according to their own understanding. Thus, there might be some measurement errors. In addition, there are various ways to measure happiness. In general, previous research divided the measurement of happiness into two dimensions, including both positive measurements (Kahneman and Krueger 2006), e.g., life satisfaction, happiness, health, etc., and negative measurements of "de-happiness" (Blore et al. 2011), e.g., illness, anxiety, depression, etc. This study used a single positive measurement index to analyze the relationship between religion and the positive measurement of happiness. In future studies, we will verify the influence of religion on negative measurements of happiness and the heterogeneity of this influence in the context of Chinese culture.

\section{Conclusions}

This study mainly examines the relationship between religion and happiness by using the data of CGSS 2015. We found that religious beliefs and religious participation correlate with believers' happiness. Specifically, Muslims are more likely to feel very happy compared to non-Muslims, whereas people of Christian faith do not significantly rate higher levels of happiness. More importantly, we proposed that there is a heterogeneity of the influence of religious beliefs on happiness in different sub-samples. Specifically, religiosity does not exert a significant effect on happiness in urban and eastern groups, but this positive association exists in the remaining sub-samples: male and female groups, rural groups, higher- and lesser-educated groups, central and western groups. We also analyzed the relationship between the frequency of religious involvement and peoples' happiness in different sub-samples. The results documented that if residents have a higher frequency of participation in religious activities, they will have a higher level of happiness, but this relationship only exists in four sub-samples: male, rural, western, and lesser-educated groups.

Author Contributions: T.L. contributed in writing original draft, conceptualization, data curation, formal analysis, and methodology. L.W. contributed in supervision of the paper. Y.J. and Y.Y. contributed in data curation, methodology, review, and editing. All authors have read and agreed to the published version of the manuscript.

Funding: This work was supported by the National Social Science Foundation of China (grant number 18VZL009).

Conflicts of Interest: The authors declare no conflict of interest.

\section{References}

Abdel-Khalek, Ahmed M. 2006. Measuring happiness with a single-item scale. Social Behavior and Personality 34: 139-49. [CrossRef] 
Abu-Raiya, Hisham, Kenneth I. Pargament, and Neal Krause. 2016. Religion as problem, religion as solution: Religious buffers of the links between religious/spiritual struggles and well-being/mental health. Quality of Life Research 25: 1265-74. [CrossRef]

Ajrouch, Kristine J., Alysia Y. Blandon, and Toni C. Antonucci. 2005. Social Networks Among Men and Women: The Effects of Age and Socioeconomic Status. Journal of Gerontology: Social Sciences 60: S311. [CrossRef] [PubMed]

Andrews, Frank M., and Stephen B. Withey. 1976. Social Indicators of Well-Being. New York: Plenim Press.

Ashiwa, Yoshiko, and David L. Wank. 2006. The politics of a reviving Buddhist temple: State, association, and religion in southeast China. Journal of Asian Studies 65: 337-59. [CrossRef]

Azzi, Corry, and Ronald Ehrenberg. 1975. Household allocation of time and church attendance. Journal of Political Economy 83: 27-56. [CrossRef]

Barro, Robert, and Joshua Mitchell. 2004. Religious Faith and Economic Growth: What Matters Most-Beliefor Belonging? Washington, DC: Heritage Foundation.

Beit-Hallahmi, Benjamin, and Michael Argyle. 1997. The Psychology of Religious Experience, Belief and Behaviour. New York: Routledge.

Bian, Yanjie, Lei Zhang, Jianke Yang, Xiaoxian Guo, and Ming Lei. 2015. Subjective Wellbeing of Chinese People: A Multifaceted View. Social Indicators Research 121: 75-92. [CrossRef]

Blore, Jed D., Mark A. Stokes, David Mellor, Lucy Firth, and Robert A. Cummins. 2011. Comparing Multiple Discrepancies Theory to Affective Models of Subjective Wellbeing. Social Indicators Research 100: 1-16. [CrossRef]

Brown, Philip H., and Brian Tierney. 2009. Religion and subjective well-being among the elderly in China. The Journal of Socio-Economics 38: 310-19. [CrossRef]

Campante, Filipe, and David Yanagizawa-Drott. 2015. Does Religion Affect Economic Growth and Happiness? Evidence from Ramadan. Quarterly Journal of Economics 130: 615-58. [CrossRef]

Chatters, Linda M. 2000. Religion and Health: Public Health Research and Practice. Annual Review of Public Health 21: 335-67. [CrossRef]

Chen, Yunsong, and Xiaoguang Fan. 2015. Discordance between subjective and objective social status in contemporary China. Journal of Chinese Sociology 2: 1-20. [CrossRef]

Chen, Yunsong, and Mark Williams. 2016. Subjective well-being in the new China: Religion, social capital, and social status. British Journal of Sociology 67: 719-46. [CrossRef] [PubMed]

Dehejia, Rajeev, Thomas DeLeire, and Erzo F. P. Luttmer. 2007. Insuring consumption and happiness through religious organizations. Journal of Public Economics 91: 259-79. [CrossRef]

Diener, Ed. 1984. Subjective well-being. Psychological Bulletin 95: 542-75. [CrossRef]

Diener, Ed, Jeff Horwitz, and Robert A. Emmons. 1985. Happiness of the very wealth. Social Indicators Research 16: 263-74. [CrossRef]

Diener, Ed, Louis Tay, and David G. Myers. 2011. The Religion Paradox: If Religion Makes People Happy, Why Are So Many Dropping Out? Journal of Personality and Social Psychology 101: 1278-90. [CrossRef]

Easterlin, Richard A. 1974. Does Economic Growth Improve the Human Lot? Some Empirical Evidence. In Nations and Households in Economic Growth. Edited by Paul A. David and Melvin Warren Reder: Academic Press, pp. 89-125.

Easterlin, Richard A., Laura Angelescu McVey, Malgorzata Switek, Onnicha Sawangfa, and Jacqueline Smith Zweig. 2010. The happiness-income paradox revisited. Proceedings of the National Academy of Sciences of the United States of America 107: 22463-68. [CrossRef]

Edgell, Penny, Joseph Gerteis, and Douglas Hartmann. 2006. Atheists as “Other": Moral boundaries and cultural membership in American society. American Sociological Review 71: 211-34. [CrossRef]

Eichhorn, Jan. 2011. Happiness for Believers? Contextualizing the Effects of Religiosity on Life-Satisfaction. European Sociological Review 28: 583-93. [CrossRef]

Ellison, Christopher G. 1991. Religious Involvement and Subjective Well-Being. Journal of Health and Social Behavior 32: 80-99. [CrossRef]

Ellison, Christopher G., and Jeffrey S. Levin. 1998. The Religion-Health Connection: Evidence, Theory, and Future Directions. Health Education \& Behavior 25: 700-20.

Ellison, Christopher G., David A. Gay, and Thomas A. Glass. 1989. Does Religious Commitment Contribute to Individual Life Satisfaction? Social Forces 68: 100-23. [CrossRef] 
Ferriss, Abbott L. 2002. Religion and the Quality of Life. Journal of Happiness Studies 3: 199-215. [CrossRef]

Francis, Leslie J., Yaacov J. Katz, Yaacov Yablon, and Mandy Robbins. 2004. Religiosity, Personality, and Happiness: A Study among Israeli Male Undergraduates. Journal of Happiness Studies 5: 315-33. [CrossRef]

Fredrickson, Barbara L. 2002. How Does Religion Benefit Health and Well-Being? Are Positive Emotions Active Ingredients? Psychological Inquiry 13: 209-13.

Heyer-Gray, Zoey A. 2000. Gender and Religious Work. Sociology of Religion 61: 467-71. [CrossRef]

$\mathrm{Hu}$, Anning, Xiaozhao Yousef Yang, and Weixiang Luo. 2017. Christian Identification and Self-Reported Depression: Evidence from China. Journal for the Scientific Study of Religion 56: 765-80. [CrossRef]

Kahneman, Daniel, and Alan B. Krueger. 2006. Developments in the measurement of subjective well-being. Journal of Economic Perspectives 20: 3-24. [CrossRef]

Krause, Neal, Christopher G. Ellison, Benjamin A. Shaw, John P. Marcum, and Jason D. Boardman. 2001. Church-Based Social Support and Religious Coping. Journal for the Scientific Study of Religion 40: 637-56. [CrossRef]

Krok, Dariusz. 2014. The Religious Meaning System and Subjective Well-Being The Mediational Perspective of Meaning in Life. Archive for the Psychology of Religion 36: 253-73. [CrossRef]

Levin, Jeff. 2011. Religion and positive well-being among Israeli and diaspora Jews: Findings from the World Values Survey. Mental Health Religion \& Culture 15: 709-20.

Levin, Jeff. 2014. Religion and Happiness Among Israeli Jews: Findings from the ISSP Religion III Survey. Journal of Happiness Studies 15: 593-611. [CrossRef]

Lim, Chaeyoon, and Robert D. Putnam. 2010. Religion, Social Networks, and Life Satisfaction. American Sociological Review 75: 914-33. [CrossRef]

Lin, Nan, Walter M. Ensel, Ronald S. Simeone, and Wen Kuo. 1979. Social Support, Stressful Life Events, and Illness: A Model and an Empirical Test. Journal of Health and Social Behavior 20: 108-19. [CrossRef] [PubMed]

Lu, Yunfeng. 2012. Understanding the Rise of Religion in China. Chinese Sociological Review 45: 3-7. [CrossRef]

Lu, Jun, and Qin Gao. 2017. Faith and Happiness in China: Roles of Religious Identity, Beliefs, and Practice. Social Indicators Research 132: 273-90. [CrossRef]

Lun, Vivian Miu-Chi, and Michael Harris Bond. 2013. Examining the Relation of Religion and Spirituality to Subjective Well-Being Across National Cultures. Psychology of Religion and Spirituality 5: 304-15. [CrossRef]

MacInnis, Donald. 1996. From suppression to repression: Religion in China today. Current History 95: $284-89$.

McFarland, Michael J. 2010. Religion and Mental Health Among Older Adults: Do the Effects of Religious Involvement Vary by Gender? Journals of Gerontology-Series B Psychological Sciences and Social Sciences 65B: 621-30.

Moberg, David O. 1965. Religiosity in old age. Gerontologist 5: 78-87. [CrossRef]

Mochon, Daniel, Michael I. Norton, and Dan Ariely. 2011. Who Benefits from Religion? Social Indicators Research 101: 1-15. [CrossRef]

Myers, David G. 2000. The funds, friends, and faith of happy people. American Psychologist 55: 56-67. [CrossRef] [PubMed]

Nanbu, Hirotaka. 2008. Religion in Chinese education: From denial to cooperation. British Journal of Religious Education 30: 223-34. [CrossRef]

National Survey Research Center. 2006. Chinese General Social Survey (2006). Beijing: National Survey Research Center.

National Survey Research Center. 2013. Chinese General Social Survey (2013). Beijing: National Survey Research Center.

National Survey Research Center. 2015. Chinese General Social Survey (2015). Beijing: National Survey Research Center.

Park, Crystal L. 2005. Religion as a meaning-making framework in coping with life stress. Journal of Social Issues 61: 707-29. [CrossRef]

Potter, Pitman B. 2003. Belief in Control: Regulation of Religion in China. In Religion in China Today. Edited by Daniel L. Overmyer and Richard Edmonds. New York: Cambridge University.

Rizvi, Mohd Ahsan Kabir, and Mohammad Zakir Hossain. 2017. Relationship Between Religious Belief and Happiness: A Systematic Literature Review. Journal of Religion \& Health 56: 1561-82.

Snoep, Liesbeth. 2008. Religiousness and happiness in three nations: A research note. Journal of Happiness Studies 9: 207-11. [CrossRef] 
Sosis, Richard. 2000. Religion and intragroup cooperation: Preliminary results of a comparative analysis of utopian communities. Cross-Cultural Research: The Journal of Comparative Social Science 34: 70-87. [CrossRef] Stark, Rodney, and Eric Y. Liu. 2011. The religious awakening in China. Review of Religious Research 52: 282-89.

Stavrova, Olga, Detlef Fetchenhauer, and Thomas Schlösser. 2013. Why are religious people happy? The effect of the social norm of religiosity across countries. Social Science Research 42: 90-105. [CrossRef]

Sun, Yingying, and Yue Zhang. 2019. Who Is Happier in China? Exploring Determinant Factors Using Religion as a Moderator. International Journal of Environmental Research and Public Health 16: 4308. [CrossRef]

Wei, Dedong, and Eric Y. Liu. 2013. Religious Involvement and Depression: Evidence for Curvilinear and Stress-Moderating Effects Among Young Women in Rural China. Journal for the Scientific Study of Religion 52: 349-67. [CrossRef]

Wilkins, Amy C. 2008. "Happier than Non-Christians": Collective emotions and symbolic boundaries among evangelical Christians. Social Psychology Quarterly 71: 281-301. [CrossRef]

Williams, Richard. 2005. Gologit2: Generalized Logistic Regression/ Partial Proportional Odds Models for Ordinal Dependent Variables. Available online: http://www.nd.edu/ \{\}rwilliam/gologit2 (accessed on 17 July 2020).

Xu, Xixiong, Yaoqin Li, Xing Liu, and Weiyu Gan. 2017. Does religion matter to corruption? Evidence from China. China Economic Review 42: 34-49. [CrossRef]

Yang, Fenggang. 2006. The red, black, and gray markets of religion in China. Sociological Quarterly 47: 93-122. [CrossRef]

Yang, Fenggang. 2010. Religion in China under Communism: A Shortage Economy Explanation. Journal of Church and State 52: 3-33. [CrossRef]

Yang, Fenggang, and Anning Hu. 2012. Mapping Chinese Folk Religion in Mainland China and Taiwan. Journal for the Scientific Study of Religion 51: 505-21. [CrossRef]

Zhang, Jing Hua, Wen Chi Zou, and Xiao Yang Jiang. 2019. One Religion, Two Tales: Religion and Happiness in Urban and Rural Areas of China. Religions 10: 532. [CrossRef]

(C) 2020 by the authors. Licensee MDPI, Basel, Switzerland. This article is an open access article distributed under the terms and conditions of the Creative Commons Attribution (CC BY) license (http://creativecommons.org/licenses/by/4.0/). 